\title{
Study of role of bacterial vaginosis in pelvic inflammatory disease, infertility and preterm labor
}

\author{
Rangari AA $\mathbf{A}^{1}$, Jakhar $\mathbf{A}^{\mathbf{2}}$ \\ ${ }^{1}$ Dr Amit A Rangari (MBBS, MD), Associate Professor, ${ }^{2}$ Dr Arun Jakhar, Both are affiliated with Department of \\ Microbiology, Muzaffarnagar Medical College and Hospital, Ghasipura, Begrajpur, NH-58, Muzaffarnagar, Uttar \\ Pradesh, India.
}

Address for Correspondence: Dr Amit A. Rangari, Associate Professor, Microbiology, C2, Faculty Residences, Muzaffarnagar Medical College and Hospital, Ghasipura, Begrajpur, NH-58, Muzaffarnagar, Uttar Pradesh, India. Email:dr_amit123@yahoo.co.in

\begin{abstract}
Background and Objective: Prevention is better than cure. Bacterial vaginosis (BV) is associated with a two fold increased risk of preterm birth but its role in upper genital tract infection (pelvic inflammatory disease), tubal damage and infertility is less certain. Our study aimed at detecting the incidence of BV in infertility, preterm labour and pelvic inflammatory disease (PID). Material and Methods: Study comprised of 50 preterm labor women subjects, 12 infertile women subjects and 12 women subjects with pelvic inflammatory disease. Gram staining, Giemsa staining, KOH mount, $\mathrm{pH}$ determination of vaginal swabs from posterior fornix of women subjects of reproductive age(15 - 45 years) group who attended Gynaecology and Obstetrics OPD/IPD of our tertiary care hospitals were carried out. Results: Of the 50 preterm labor cases, $10 \%$ (5) cases were of asymptomatic BV, 46\% (23) case where of symptomatic BV. Of the 12 infertile women, $50 \%$ (6) cases were diagnosed to have BV. Of the 12 women with PID, $83 \%$ (10) cases were diagnosed to have BV. Conclusion: Most of the complications due to BV like pelvic inflammatory disease, infertility, preterm labor can be prevented if BV is diagnosed early and treated. In view of the potentially serious complications associated with $\mathrm{BV}$, a routine screening of these patients is essential and simple tests like Gram Stain, Giemsa Stain, monitoring of $\mathrm{pH}$ should be recommended to be included as a routine screening test as part of Antenatal Care.
\end{abstract}

Keywords: Bacterial Vaginosis, Infertility, Pelvic Inflammatory Diseases, Preterm Labor.

\section{Introduction}

The perinatal mortality and morbidity associated with preterm deliveries very high due to early neonatal death, respiratory distress syndrome, intraventricular hemorrhage, birth asphyxia, hyperbilirubinemia, hypothermia, cerebral palsy. Therefore, preterm labour and the complications of preterm deliveries are the most common, costly and catastrophic complication of pregnancy. Besides this, the emotional trauma to parents of such babies cannot be accounted. Hence for preterm labour prevention is better than cure. Despite preterm delivery being the major contributor to perinatal morbidity and mortality globally, the incidence of preterm labour has not changed for many years. Neonatology has advanced and the survival of

Manuscript received: $26^{\text {th }}$ Oct 2015

Reviewed: $8^{\text {th }}$ Nov 2015

Author Corrected: $20^{\text {th }}$ Nov 2015

Accepted for Publication: $30^{\text {th }}$ Nov 2015 babies has improved, but handicap continues to occur in babies born at earlier gestation. However, the management of preterm labour has changed very little during the last 30 years. Despite their side effects, beta mimetic agents are still used to arrest preterm labour along with corticosteroids. The reason for our inability to manage or prevent preterm labour adequately is simply the lack of knowledge of its cause. There is a strong association between preterm delivery and low socioeconomic status, maternal weight prior to pregnancy, history of previous preterm births and multifetal gestation. A fairly large number of spontaneous preterm births are associated with genital tract infection and those occurring before 30weeks gestation are even more likely to be infection related. Therefore, infection associated preterm birth represents an attractive area for intervention. Infections at multiple sites are associated with spontaneous preterm birth. 
Bacterial vaginosis (BV) is associated with a two fold increased risk of preterm birth with the greatest risk when bacterial vaginosis is present before 20 weeks of gestation. This may indicate a critical period during early gestation when BV related organisms can gain access to the upper genital tract and set the stage for preterm labour later in gestation. BV is a syndrome in which the vaginal flora is no longer dominated by lactobacilli and there is an over growth of Gardnerella vaginalis (Gram variable coccobacillus), Mobiluncus species, Mycoplasma hominis, Peptostreptococcus species and certain Anaerobic bacteria [1, 2]. Bacterial Vaginosis is one of the common causes of vaginitis in women who are sexually active during child bearing age [3]. The manifestation vary from asymptomatic state $(\geq 50 \%)$ to increased thin, homogenous, grayish white, foul smelling, vaginal discharge, pruritus. Among symptomatic patients, vaginal discharge is being the most common clinical complaint of women of reproductive age in many parts of the world [4]. PH changes and change in normal vaginal flora allow anaerobic microbes to flourish and cause infection [5]. In pregnant women $\mathrm{BV}$ is associated with the presence of fibronectin which directly correlates with 16 fold increase in clinical chorio-aminionitis, 6 fold increases in neonatal sepsis and is also associated with intraamniotic infection. BV in women at 23 to 26 weeks of gestation is associated with intra- amniotic fluid infection at term. [6].BV also has very wide medical, psychological and social repercussions on patient. Additional possible adverse outcomes of bacterial vaginosis include an increased frequency of abnormal Papanicolaou (Pap) smears, pelvic inflammatory disease (PID) and endometritis [7,8,9]. Vaginal cuff cellulites, pelvic inflammatory disease and endometritis can occur if invasive gynaecological procedures or surgeries are performed when a patient has bacterial vaginosis $[10,11,12]$. Bacterial vaginosis has been consistently associated with preterm delivery, but its role in upper genital tract infection (pelvic inflammatory disease), tubal damage and infertility is less certain [13]. This study dealt with the detection of changes in normal vaginal microbialflora as the cause for preterm labour. Our study aimed at detecting the incidence of Bacterial Vaginosis in pelvic inflammatory disease, infertility and preterm labour.

\section{Material and Methods}

Study protocol was reviewed and approved by institutional review board. The present observational and prospective study was conducted in the Microbiology department at our Tertiary care Hospital. After getting informed verbal consent subjects age, pregnancy status, parity, ethnicity, mode of contraception, number of sexual partners, presence or absence of symptoms, and a sexually transmitted diseases history were recorded. Subjects on systemic antibiotic therapy or local vaginal antimicrobial therapy within the preceding 2 weeks, menstruating at the time of the examination, cervical cerclage, vaginal bleeding, placenta previa, spermicide use, recent douching, or sexual intercourse within 24 hours were excluded from our study. Study comprised of 50 preterm labor women subjects, 12 infertile women subjects and 12 women subjects with pelvic inflammatory disease. Gram staining, Giemsa staining, $\mathrm{KOH}$ mount, $\mathrm{pH}$ determination of Vaginal Swabs from Posterior fornix of women subjects of reproductive age $(15$ - 45 years $)$ group who attended Gynaecology and Obstetrics OPD/IPD ourtertiary care hospitals were carried out. Amsel's Clinical criteria and Nugent's microbiological criteria for diagnosis of BV were elicited [14].

Statistical Analysis:-Data in our study were statistically evaluated, compared and probability values (P) were calculated by using $\mathrm{Z}$ test . Probability values of $<0.05$ were considered significant with $95 \%$ level of significance (i.e. confidence interval of 95. Also the data was compared by using Ms Excel software.

\section{Results}

Table 1: Coexistence observed between bacterial vaginosis and preterm labor

\begin{tabular}{|l|l|l|}
\hline Total cases of Preterm-50 & $\begin{array}{l}\text { Intermediate Bacterial Vaginosis } \\
\text { No\% }\end{array}$ & $\begin{array}{l}\text { Definite Bacterial Vaginosis } \\
\text { No\% }\end{array}$ \\
\hline Asymptomatic Bacterial Vaginosis & $3(6)$ & $2(4)$ \\
\hline SymptomaticBacterial Vaginosis & $12(24)$ & $11(22)$ \\
\hline
\end{tabular}

Total cases of Bacterial vaginosis in Preterm $\rightarrow 28$

No Bacterial vaginosis in Preterm $\rightarrow 22$.

Vaginal Candidiasis in Preterm $\rightarrow 12$ 
Trichomonas Vaginitis in Preterm $\rightarrow 0$

Figure 1:- Coexistence observed between bacterial vaginosis and preterm labor

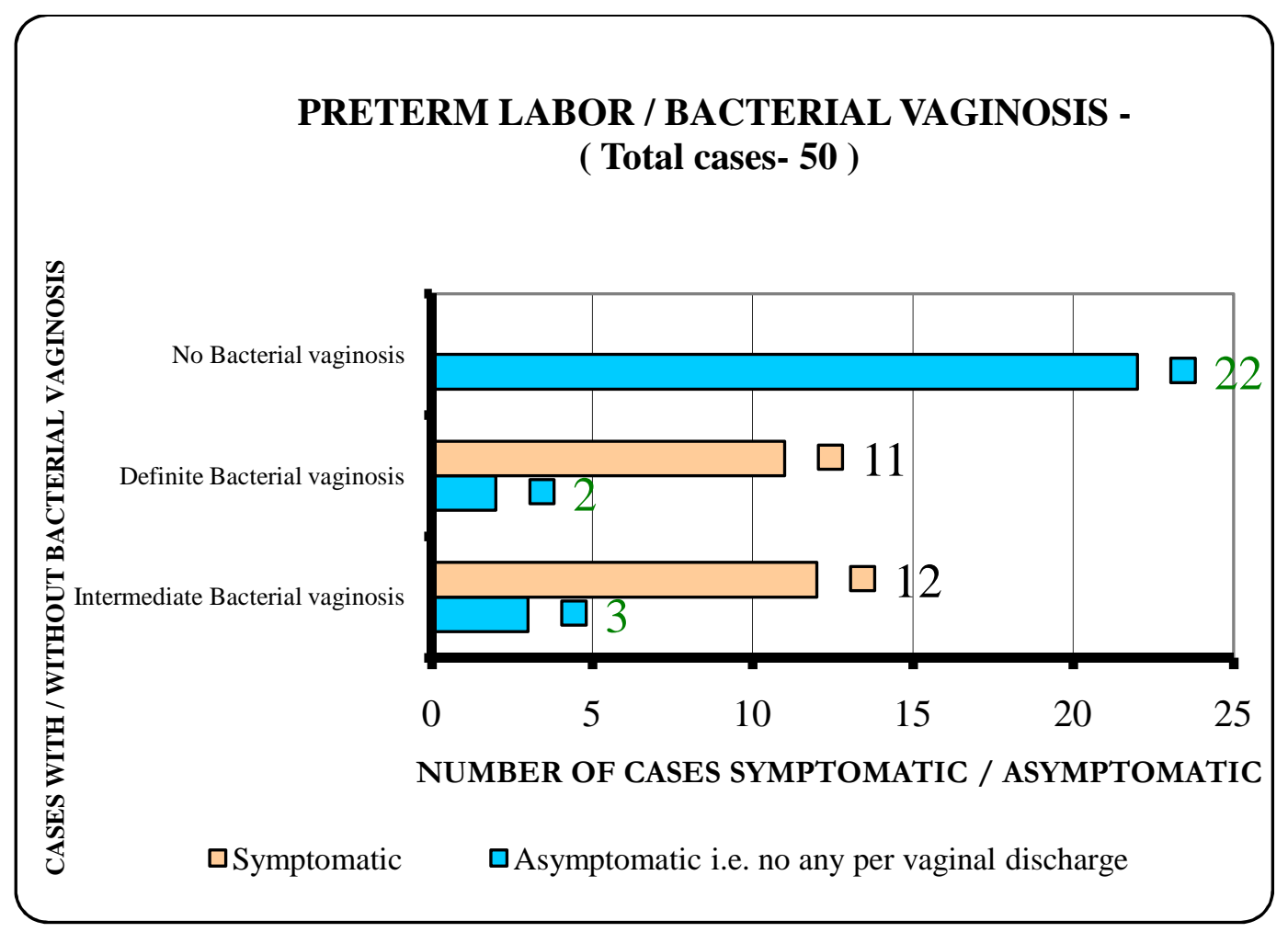

Statistically on applying $\mathbf{Z}$ test for comparing the diagnostic inference by Nugent criteria on Gram staining of vaginal smear of preterm labor women cases diagnosed to have symptomatic and asymptomatic bacterial vaginosis, it was found that $\mathrm{Z}$ value $=3.786$ and $\mathrm{P}$ value $=0.00$. Thus Nugent diagnostic criteria were highly statistically significant in diagnosing both symptomatic and asymptomatic bacterial vaginosis in preterm labor cases.

Table 2: Coexistence observed between bacterial vaginosis and infertility

\begin{tabular}{|c|c|c|c|}
\hline Total cases of Infertility-12 & $\begin{array}{l}\text { Intermediate Bacterial } \\
\text { vaginosis } \\
\text { No\% }\end{array}$ & $\begin{array}{l}\text { Definite Bacterial } \\
\text { vaginosis } \\
\text { No\% }\end{array}$ & $\begin{array}{l}\text { No Bacterial } \\
\text { Vaginosis } \\
\text { No\% }\end{array}$ \\
\hline Asymptomatic & $(16.6)$ & $(8.3)$ & $0 \quad(0)$ \\
\hline Symptomatic & $(25)$ & $0(0)$ & $6(50)$ \\
\hline
\end{tabular}

Table 3:- Coexistence observed between bacterial vaginosis and pelvic inflamatory disease (PID):-

\begin{tabular}{|l|l|l|l|}
\hline $\begin{array}{l}\text { Total cases of Pelvic } \\
\text { Inflammatory Disease }\end{array}$ & $\begin{array}{l}\text { Intermediate Bacterial } \\
\text { vaginosis } \\
\text { No\% }\end{array}$ & $\begin{array}{l}\text { Definite Bacterial } \\
\text { vaginosis } \\
\text { No\% }\end{array}$ & $\begin{array}{l}\text { No Bacterial } \\
\text { Vaginosis } \\
\text { No\% }\end{array}$ \\
\hline 12 & $8(66)$ & $2(17)$ & $2(17)$ \\
\hline
\end{tabular}


Figure 2:- Coexistence observed between bacterial vaginosis and infertility

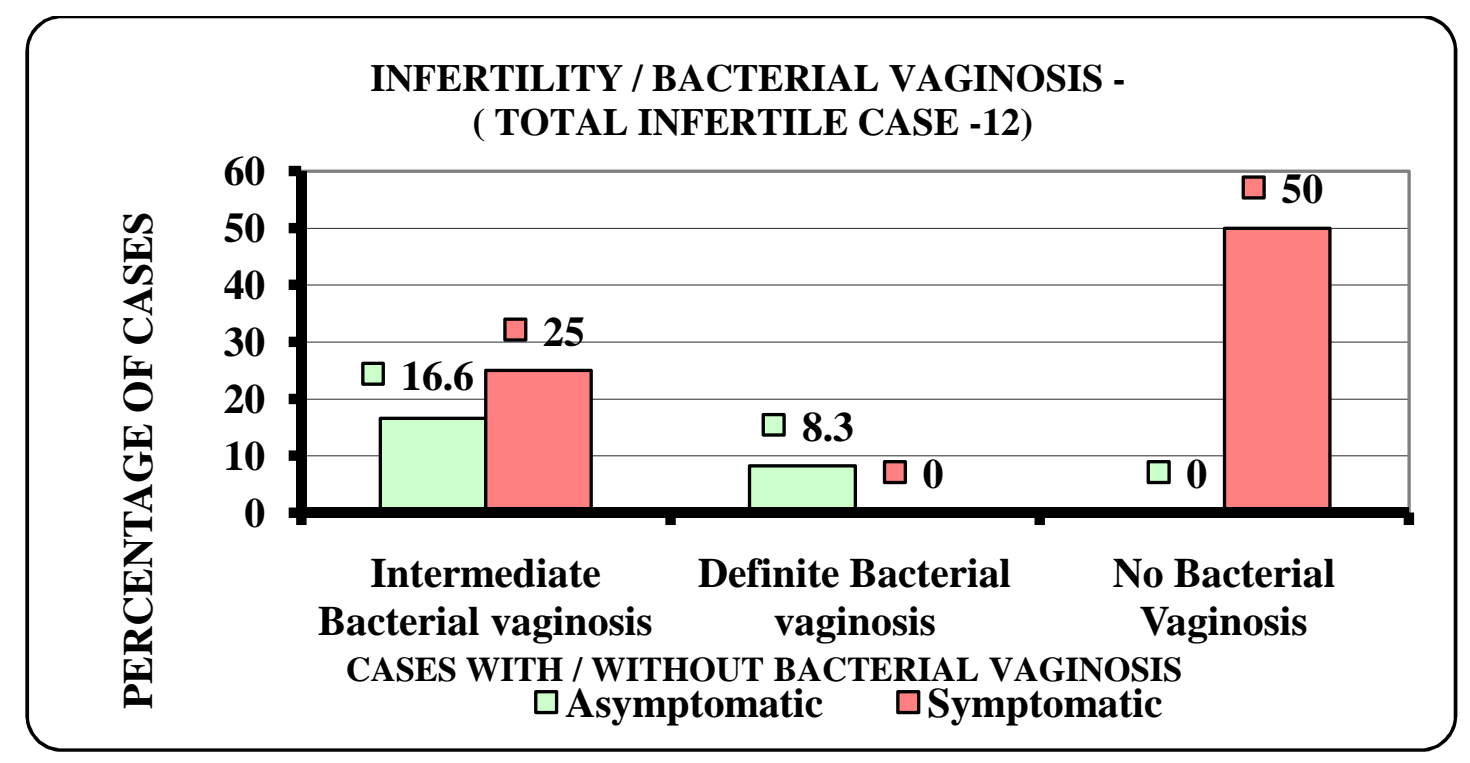

\section{Discussion}

Previously considered a benign condition, BV has been related to many gynaecological conditions and complications of pregnancy including pelvic inflammatory disease, post hysterectomy vaginal cuff cellulitis, endometritis, amniotic fluid infection, preterm delivery, preterm labor, premature rupture of the membranes and possibly, spontaneous abortion [15]. However, BV if suspected at an early stage can be easily diagnosed and treated. In our study as shown in Table1, out of the total 50 preterm labor cases studied, $6 \%$ (3) case were of asymptomatic intermediate bacterial vaginosis, 4\%(2)case where of asymptomatic definite bacterial vaginosis, $24 \%$ (12)case where of symptomatic intermediate bacterial vaginosis, $22 \%(11)$ case where of symptomatic definite bacterial vaginosis. Bacterial vaginosis is associated with reproductive health morbidity, including pelvic inflammatory disease [16], preterm birth, premature rupture of membranes [17] chorioamnionitis [18], spontaneous abortion [19], and post-gynecologic surgery infection [20]. From the available studies that focus largely on sexually transmitted disease (STD) clinic patients and pregnant women, according to Sonnex $\mathrm{C}$ et al bacterial vaginosis prevalence is estimated to range from $7 \%$ among asymptomatic women attending general practice clinics[21] to $46 \%$ among women attending STD clinics[4] according to Eschenbach DA et al. Deborah B et al [22]reported that bacterial vaginosis (BV) during pregnancy increases a woman's risk of delivering before the 37th week of pregnancy (preterm, or premature, labor). Bacterial vaginosis is a common vaginal infection that affects $12-22 \%$ of pregnant women. The vast majority of epidemiologic research designed to examine the role of $\mathrm{BV}$ and adverse pregnancy outcomes has focused on the risk of preterm delivery, although many of these studies incorrectly combined preterm labor and preterm, premature rupture of the membranes. In any case, the studies of Kurki $\mathrm{T}$ et al, Hillier SL at al and Gratocos E et al, they have consistently shown a twofold increased risk of preterm delivery among women diagnosed with BV, particularly $\mathrm{BV}$ diagnosed in the early second trimester [23, 24]. A recent meta-analysis reviewing studies examining the role of $\mathrm{BV}$ and the risk of preterm delivery reported a summary odds ratio of 1.6 , indicating a 60 percent increased risk of preterm delivery among pregnant women with BV. A smaller number of studies have assessed the relation between $\mathrm{BV}$ and the outcomes of premature labor, low birth weight, and premature rupture of the membranes. Kurki $\mathrm{T}$ et al's study examining several pregnancy outcomes related to $\mathrm{BV}$ diagnosed during the first trimester of pregnancy reported a 2.6-fold increased risk of preterm labor a 6.9fold increased risk of preterm delivery, and a 7.3-fold increased risk of preterm, premature rupture of the membranes [23]. Another study ofPurwar $M$ et al, found that $\mathrm{BV}$ diagnosed in the second trimester was associated with an increased risk of preterm delivery and premature rupture of the membranes and that $\mathrm{BV}$ accounted for83 percent of the attributable risk for preterm birth [25].Joan $\mathrm{M}$ et al[26] in their study reported preterm birth as a major cause of perinatal 
morbidity and mortality. Hillier et al[1] found that women with bacterial vaginosis in the second trimester were $40 \%$ more likely to have preterm delivery of lowbirth-weight infants than women without it. Hauth et al[27] reported that treatment of bacterial vaginosis with metronidazole and erythromycin reduced rates of preterm births in women with bacterial vaginosis and in those with increased risk of preterm delivery. In studies of Briselden $\mathrm{M}$ et al, McGregor JA et al, PlatzChristensen JJ ,Mattsby-Baltzer I et al , PlatzChristensen JJ, Brandberg A et al[s2] and Cauci S et al, BV diagnosed from the lower genital tract has been related to 1) an increased potential for other vaginal pathogens togain access to the upper genital tract, 2) the presence of enzymes that reduce the ability of leukocytes to reduce infection, and 3) an increased level of endotoxins stimulating cytokine and prostaglandin production[28,29,30,31,32]. In fact, Imseis et al. reported higher vaginal levels of interleukin-1 beta, an inflammatory cytokine, among pregnant women with BV, and Spandorfer et al found higher levels of both cervical interleukin-1 beta andinterleukin-8 cytokine levels among non pregnant women with BV[33,34]. As mentioned in studies of Hay PE et al, McGregor JA et al and Ralph SG et al a growing body of literature has begun to suggest an increased risk of spontaneous abortion among pregnant women with BV [29,35,36]. Their Studies have reported a three to five fold increased risk of spontaneous abortion among pregnant women with BV in the first trimester, although these studies were hampered by small sample size. Two additional studies by McGregor JA et al and LlahiCamp JM et al among high-risk pregnant women also reported an increase in spontaneous abortion among women diagnosed with BV [37]. Paul J keis et al [38] detected bacterial vaginosis at 28 weeks of pregnancy in patients who had much higher incidence of preterm labor.

In our study as shown in Table 2, out of the 12 inferile women $50 \%$ (6) cases were diagnosed to have bacterial vaginosis. Out of which 3 were symptomatic (3 diagnosed as intermediate $\mathrm{BV}$ ) and 3 were asymptomatic (2 diagnosed as intermediate BV, 1 diagnosed as Definite BV).Ralph SG et al's[35]study enrolling women undergoing infertility treatment found more than a two fold increased risk of spontaneous abortion among women with BV after adjustment for maternal age, prior live birth, and self-reported cigarette smoking.
In our study as shown in Table 3, out of the 12 women with PID, 66\%(8) cases were diagnosed to have intermediate bacterial vaginosis and $17 \%$ (2)cases with Definite bacterial vaginosis. While $17 \%$ (2) cases with PID showed no bacterial vaginosis. PID is believed to result from direct ascending canalicular spread of microorganisms from the vagina and endocervix to the endometrial, fallopian tube mucosa and upper genital sites [39]. Women with PID are at increased risk of chronic pelvic pain, ectopic pregnancy, and tubal infertility [40,41]. Multiple organisms have been implicated as etiologic agents in PID, and most cases of PID are associated with more than one organism. In addition to $\mathrm{C}$. trachomatis and $\mathrm{N}$. gonorrhoeae, a wide variety of anaerobic and aerobic (facultative) bacteria have been isolated from the upper-genital tracts of $25 \%$ $50 \%$ of women with acute PID. The most common anaerobic bacteria found are Bacteroides, Peptostreptococcus, and Peptococcus species, whereas the most common facultative bacteria are Gardnerella vaginalis, Streptococcus species, Escherichia coil and Haemophilus influenzae [42].Westrom L et al reported that approximately $12 \%$ of women are infertile after a single episode of PID, almost $25 \%$ after two episodes, and over $50 \%$ after three or more episodes [40]. According to Eschenbach DA et al, the syndrome bacterial vaginosis (BV) has also been suggested as an antecedent to lower-genital-tract infection that leads to polymicrobial acute $\mathrm{PID}[42]$; the organisms involved in $\mathrm{BV}$ are similar to the nongonococcal, nonchlamydial bacteria frequently isolated from the upper-genital-tract of women with acute PID. At least four factors could contribute to the ascent of these bacteria and/or be associated with the pathogenesis of upper-genital- tract infection. First, uterine instrumentation (e.g., the insertion of an intrauterine device) facilitates upward spread of vaginal and cervical bacteria. Second, the hormonal changes during menses, as well as menstruation itself, leads to cervical alterations that may result in loss of a mechanical barrier preventing ascent. Also, the bacteriostatic effect of cervical mucus is lowest at the onset of menses. Third, retrograde menstruation may favor ascent to the tubes and peritoneum. Finally, individual organisms may have potential virulence factors associated with the pathogenesis of acute chlamydial and gonococcal PID [39]. Many women with PID have minimal symptoms, and some are believed to experience no symptoms ("silent PID").

\section{Summary and Conclusion}


Evidence suggests that bacterial vaginosis is a risk factor for premature rupture of membranes (PROM) and preterm labor. Early diagnosis and treatment of bacterial vaginosis (BV) infection in pregnancy decreases the risk of preterm labor and its sequel. Hence for preterm labor, 'Prevention Is Better Than Cure'. Most of the complications due to BV like Pelivic inflammatory disease, infertility can be prevented if diagnosed early. A constant surveillance in preterm women for BV, especially in the asymptomatic cases, may prevent peri-natal morbidity due to this infection. As a routine screening method at antenatal work up and also in women admitted in antenatal ward as threatened or established preterm labour, tests detecting changes in normal vaginal microbialflora during pregnancy are must. In view of the potentially serious complications associated with $\mathrm{BV}$, a routine screening of these patients is essential and simple tests like Gram Stain, Giemsa Stain , monitoring of $\mathrm{pH}$ should be recommended to be included as a routine screening test as part ofAnte-Natal Care. Gram Stain is a very reliable method for the detection of BV. It is a rapid technique which is simple and Cost- effective to detect the change in the normal vaginal bacterial flora.

Acknowledgement: Authors are thankful for the kind co-operation received from laboratory technicians and other teaching staff members of Microbiology department.

\section{Funding:Nil. Conflict of interest: Nil. Permission for IRB: Yes.}

\section{References}

\section{References}

1. Hillier SL, Krohn MA, Rabe LK, Klebanoff SJ, Eschenbach DA. The normal vaginal flora, H2O2producing lactobacilli, and bacterial vaginosis in pregnant women. Clin Infect Dis. 1993 Jun;16 Suppl 4:S273-81.

2. Spiegel CA, Amsel R, Eschenbach D, Schoenknecht F, Holmes KK. Anaerobic bacteria in nonspecific vaginitis. N Engl J Med. 1980 Sep 11;303(11):601-7.

3. P..Rao , S.Devi, A.Shriyan, M.Rajaram, K. Jagdishchandra ; Diagnosis of Bacterial Vaginosis in a Rural Set up : Comparison of clinical Algorithm, Smear Scoring and Culture by Semiquantitave Technique,
Indian Journal of Medical Microbiology, 2004 ;22(1) : 47- 50.

4. ESCHENBACH DA, HILlIER S, CRITCHLOW

C, Stevens C, DeRouen T, Holmes KK. Diagnosis AND CLINICAL MANIFESTATIONS OF BACTERIAL VAGINOSIS. AM J OBSTET GYNECOL. 1988 APR;158(4):819-28.

5. Ramani Bai JT, K R.Legori M. Prevalence of Bacterial Vaginosis in women attending Antenatal, Gynecology and STD Clinics of Medical College ,Thiruvananthapurum. J Academy Clinical Microbiologist. 1998;I;107-11.

6. BARBARA A. MAJERONI. Bacterial Vaginosis An Update. Am Fam Physician. 1998 Mar 15;57(6):1285-1289.

7. Eltabbakh GH, Eltabbakh GD, Broekhuizen $\mathrm{FF}$, Griner BT.

Value of wet mount and cervical cultures at the time of cervical cytology in asymptomatic women. Obstet Gynecol. 1995 Apr;85(4):499-503.

8. Soper DE, Brockwell NJ, Dalton HP, Johnson D. Observations concerning the microbial etiology of acute salpingitis. Am J Obstet Gynecol. 1994 Apr;170(4):1008-14; discussion 1014-7.

9. Korn AP, Bolan G, Padian N, Ohm-Smith M, Schachter J, Landers DV. Plasma cell endometritis in women with symptomatic bacterial vaginosis. Obstet Gynecol. 1995 Mar;85(3):387-90.

10. Sobel JD. N Engl J Med. 1997 Dec 25;337(26):1896-903.

11. Kent HL. Epidemiology of vaginitis. Am J Obstet Gynecol. 1991 Oct;165(4 Pt 2):1168-76.

12. Hill GB. The microbiology of bacterial vaginosis. Am J Obstet Gynecol. 1993 Aug;169(2 Pt 2):450-4.

13. Morris M, Nicoll A, Simms I, Wilson J, Catchpole M. Bacterial vaginosis: a public health review. BJOG. 2001 May;108(5):439-50.

14. Nugent RP, Krohn MA, Hillier SL. Reliability of diagnosing bacterial vaginosis is improved by a 
standardized method of gram stain interpretation. J Clin Microbiol. 1991 Feb;29(2):297-301. 15. Hay PE, Lamont RF, Taylor-Robinson D, Morgan
$\begin{array}{ll}\text { DJ, Ison } & \text { C, Pearson }\end{array}$ Abnormal bacterial colonisation of the genital tract and subsequent preterm delivery and late miscarriage. $\quad$ BMJ. $1994 \quad$ Jan 29;308(6924):295-8.

16. Peipert JF, Montagno AB, Cooper AS, Sung CJ. Bacterial vaginosis as a risk factor for upper genital tract infection. Am J Obstet Gynecol. 1997 Nov;177(5):1184-7.

17. Mercer BM, Goldenberg RL, Meis PJ, Moawad AH, Shellhaas C, Das A, Menard MK, Caritis SN, Thurnau GR, Dombrowski MP, Miodovnik M, Roberts JM,McNellis D. The Preterm Prediction Study: prediction of preterm pre mature rupture of membranes through clinical findingsand ancillary testing. The National Institute of Child Health and Human Development MaternalFetal MedicineUnits Network. Am J Obstet Gynecol. 2000 Sep;183(3):738-45.

18. Soper DE. Gynecologic sequelae of bacterial vaginosis. Int J Gynaecol Obstet. 1999 Nov;67 Suppl $1: \mathrm{S} 25-8$.

19. Donders GG, Van Bulck B, Caudron J, Londers L, Vereecken A, Spitz B. Relationship of bacterial vaginosis and mycoplasmas to the risk of spontaneous abortion. Am J Obstet Gynecol. 2000 Aug;183(2):4317.

20. Lin L, Song J, Kimber N, Shott S, Tangora J, Aroutcheva A, Mazees MB, Wells A, Cohen A, Faro $\mathrm{S}$. The role of bacterial vaginosis in infection after major gynecologic surgery. Infect Dis Obstet Gynecol. 1999;7(3):169-74.

21. Sonnex C. The amine test: a simple, rapid, inexpensive method for diagnosing bact erial vaginosis. $\mathrm{Br} \quad \mathrm{J}$ Obstet Gynaecol. 1995 Feb;102(2):160-1.

22. Nelson DB, Macones G. Bacterial Vaginosis in Pregnancy: Current Findings and Future Directions. Epidemiol Rev. 2002;24(2):102-8.
23. Kurki T, Sivonen A, Renkonen OV, Savia E, Ylikorkala O. Bacterial vaginosis in early pregnancy and pregnancy outcome. Obstet Gynecol. 1992 Aug;80(2):173-7.

24. Gratacós E, Figueras F, Barranco M, Vila J, Cararach V, Alonso PL, Fortuny A. Spontaneous recovery of bacterial vaginosis during pregnancy is not associated with an improved perinatal outcome. Acta Obstet Gynecol Scand. 1998 Jan;77(1):37-40.

25. Purwar M, Ughade S, Bhagat B, Agarwal V, Kulkarni H. Bacterial vaginosis in early pregnancy and adverse pregnancy outcome. J Obstet Gynaecol Res. 2001 Aug;27(4):175-81.

26. Mastrobattista JM, Bishop KD, Newton ER. Wet smear compared with gram stain diagnosis of bacterial vaginosis in asymptomatic pregnant women. Obstet Gynecol. 2000 Oct;96(4):504-6.

27. Hauth JC, Goldenberg RL, Andrews WW, DuBard MB, Copper RL. Reduced incidence of preterm delivery with metronidazole and erythromycin in women with bacterial vaginosis. N Engl J Med. 1995 Dec 28;333(26):1732-6.

28. Briselden AM, Moncla BJ, Stevens CE, Hillier SL. Sialidases (neuraminidases) in bacterial vaginosis and bacterial vaginosis-associated microflora. J Clin Microbiol. 1992 Mar;30(3):663-6.

29. McGregor JA, French JI, Jones W, Milligan K, McKinney PJ, Patterson E, Parker R. Bacterial vaginosis is associated with prematurity and vaginal fluid mucinase and sialidase: results of a controlled trial of topical clindamycin cream. Am J Obstet Gynecol. 1994 Apr;170(4):1048-59; discussion 105960.

30. Cauci S, Monte R, Driussi S, Lanzafame $\mathrm{P}$, Quadrifoglio F. Impairment of the mucosal immune system: IgA and IgM cleavage detected in vaginal wash ings of a subgroup ofpatients with bacterial vaginosis. J Infect Dis. 1998 Dec;178(6):1698-706.

31. Platz-Christensen JJ, Brandberg A, Wiqvist N. Increased prostaglandin concentrations in the cervical mucus of pregnant women with bacterial vaginosis. Prostaglandins. 1992 Feb;43(2):133-4. 
32. Platz-Christensen JJ, Mattsby-Baltzer I, Thomsen P, Wiqvist N. Endotoxin and interleukin-1 alpha in the cervical mucus and vaginal fluid of pregnant women with bacterial vaginosis. Am J Obstet Gynecol. 1993 Nov;169(5):1161-6.

33. Spandorfer SD, Neuer A, Giraldo PC, Rosenwaks Z, Witkin SS. Relationship of abnormal vaginal flora, proinflammatory cytokines and idiopathic infertility in women undergoing IVF. J Reprod Med. 2001 Sep;46(9):806-10.

34. Imseis HM, Greig PC, Livengood CH 3rd, Shunior E, Durda P, Erikson M. Imseis $\mathrm{HM}^{1}$, Greig PC, Livengood CH 3rd, Shunior E, Durda P, Erikson M. J Soc Gynecol Investig. 1997 Mar-Apr;4(2):90-4.

35. Ralph SG, Rutherford AJ, Wilson JD. Influence of bacterial vaginosis on conception and miscarriage in the first trimester: cohort study. BMJ. 1999 Jul 24;319(7204):220-3.

36. McGregor JA, French JI, Parker R, Draper D, Patterson E, Jones W, Thorsgard K, McFee J. Prevention of premature birth by screening and treatment for common genital tract infections: results of a prospective controlled evaluation. Am J Obstet Gynecol. 1995 Jul;173(1):157-67.

37. Llahi-Camp JM, Rai R, Ison C, Regan L, TaylorRobinson D. Association of bacterial vaginosis with a history of second trimester miscarriage. Hum Reprod. 1996 Jul;11(7):1575-8.
38. Meis PJ, Goldenberg RL, Mercer B, Moawad A, Das A, McNellis D, Johnson F, Iams JD, Thom E, Andrews WW. The preterm prediction study: significance of vaginal infections. National Institute of Child Health and Human Development Maternal-Fetal Medicine Units Network. Am J Obstet Gynecol. 1995 Oct;173(4):1231-5.

39. Rice PA, Schachter J. Pathogenesis of pelvic inflammatory disease caused by Chlamydia trachomatis and Neisseria gonorrhoeae: where should research efforts focus? In: Joint Meeting of the Centers for Disease Control and National Institutes of Health about Pelvic Inflammatory Disease Prevention, Management, and Research in the 1990s, Bethesda, Maryland, September 4-5, 1990.

40. Weström L. Incidence, prevalence, and trends of acute pelvic inflammatory disease and its consequences in industrialized countries. Am J Obstet Gynecol. 1980 Dec 1;138(7 Pt 2):880-92.

41. Cates W Jr, Rolfs RT Jr, Aral SO. Sexually transmitted diseases, pelvic inflammatory disease, and infertility: an epidemiologic update. Epidemiol Rev. 1990;12:199-220.

42. Eschenbach DA, Buchanan TM, Pollock HM, Forsyth PS, Alexander ER, Lin JS, Wang SP, Wentworth BB, MacCormack WM, Holmes KK. Polymicrobial etiology of acute pelvic inflammatory disease. N Engl J Med. 1975 Jul 24;293(4):166-71.

\section{How to cite this article?}

Rangari AA, Jakhar A. Study of role of bacterial vaginosis in pelvic inflammatory disease, infertility and preterm labor. Int J Med Res Rev 2015;3(10):1201-1208. doi: 10.17511/ijmrr.2015.i10.219. 